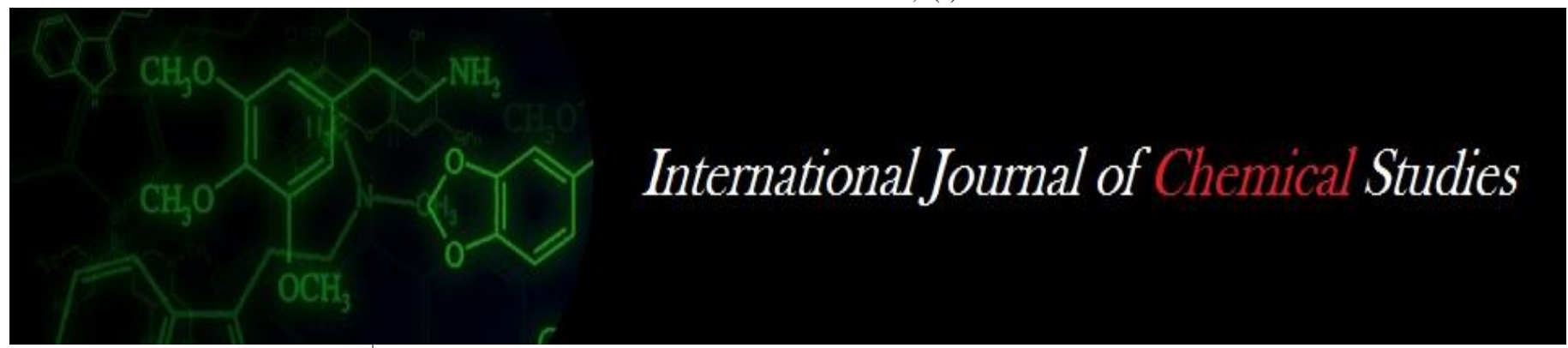

P-ISSN: 2349-8528

E-ISSN: 2321-4902

www.chemijournal.com

IJCS 2020; 8(3): 1132-1136

(C) 2020 IJCS

Received: 07-03-2020

Accepted: 09-04-2020

Nagaraju Madala

Jr. Breeder, Comienzo Agri

Science Limited, SHUATS,

Allahabad, Uttar Pradesh, India

Email:

nagarajmadala@gmail.com

Charles Wesly K

Senior Research Fellow

PJTSAU, Hyderabad, Uttar

Pradesh, India

Email:

charlesrocking.wesly@gmail.com

Manoj Kumar Nutakki

Msc Genetics and Plant

Breeding, SHUATS, Allahabad,

Uttar Pradesh, India

Email:

manojkumarnuthakki900@gmail .com

Sagar Kolluri

Msc Entomology SHUATS,

Allahabad, Uttar Pradesh, India

Email:

sagarkolluri@gmail.com
Corresponding Author:

Nagaraju Madala

Jr. Breeder, Comienzo Agri

Science Limited, SHUATS,

Allahabad, Uttar Pradesh, India

Email:

nagarajmadala@gmail.com

\section{Morphology, cultivation, diseases, importance, traditional breeding and advanced techniques in biotechnology in chilli (Capsicum annuum $\mathrm{L}$.)}

\author{
Nagaraju Madala, Charles Wesly K, Manoj Kumar Nutakki and Sagar \\ Kolluri
}

DOI: https://doi.org/10.22271/chemi.2020.v8.i3o.9351

\begin{abstract}
Present review a consolidated data of morphology, cultivation pattern, diseases attacking in chilli, breeding methods in chilli and advanced techniques in biotechnology Capsicum genus has perfect flowers where male and female reproductive structures are in the same flowers. Usage of molecular technologies will continue to advance becoming an essential tool, combined with traditional selection and crosses techniques already established in capsicum genetic breeding. Molecular markers are used to characterize the genetic structure of individuals and population's In vitro clonal propagation of chilli is relatively slower than other members of Solanaceae family because of its recalcitrant nature which makes it difficult to apply recombinant DNA technology. Capsaicin is a potent inhibitor of substance P, a neuropeptide associated with inflammatory processes. Chilli comprises of the following nutrients Proteins, Carotenoids, Fat, Vitamin A, Vitamin C, Pro-vitamines E, P, B1, B2, B3, Steroidal alkaloidal glycosides and cholesterol and sodium. Chilli's are low in saturated fat, cholesterol and sodium.
\end{abstract}

Keywords: Chilli, morphology, traditional breeding, molecular breeding, In vitro

\section{Introduction}

Chilli (Capsicum annuum L.) is important vegetable spice crops from several viewpoints. Different varieties of chilli are cultivated and are used for various uses like vegetable, pickle, spice and condiments in daily life. Chilli is the most important ingredient in different cuisines all around the world. The pungency, red color, and oleoresin contents in chilli are especially important for processed food as well as for export purpose. The coloring matter 'Capsanthin' and oleoresin content are particularly important for food and spice industries. Itadds flavour, aroma, and texture, pungency, and color and pungency level. The pungency of hot pepper is due to the accumulation of capsaicinoid, a group of alkaloids that are unique to the Capsicum genus (Sun et al., 2015) ${ }^{[11]}$. Capsaicinoids are synthesized in the placental tissue localized inside of the fruit and in this same structure seeds are adhered (Wahyuni et al., 2013) ${ }^{[13,15]}$. The world's hottest chilli "Naga Jolokia" is cultivated in Assam district in India.

Chilli was cultivated by the farmers with a primary crop to protect the primary crop from any damage the birds could do. It gained popularity in America as a Flavouringagent. In $16^{\text {th }}$ century chilli was popular in Asia and native Asian climate suited the crop well. Chilli has many medicinal properties and is used in the traditional Indian medicine system "Ayurveda". India has become the largest producer and exporter of chilli in the world. It contributes to $25 \%$ of the world's total production of chilli.

\subsection{Species}

The Capsicum genus consists of about 30 wild species and five domesticated species: $C$. annum, $C$. baccatum, $C$. chinense, $C$. frustescens, and $C$. pubescens. Fruit of capsicum may vary in size, color and shape within species. Phylogenetic relationship between species was investigated. 


\subsection{Morphology}

Chilli (Capsicum annuum L.) An herbaceous or semi-woody, annual plant during early stage of growth but becomes woody later on. The old branches become brittle with age and are easily broken. Straight, woody stems and the leaves are ovate, tapering to a sharp point, measuring up to $15 \mathrm{~cm}$, dark green on the upper surface and pale green on the lower surface. The leaves are simple, alternate, exstipulate, elliptic, lanceolate, and glabrous. Leaf area per plant and leaf length varies from 1000-3000sq.cm and 0.5-2.5 cm, respectively. Chilli plant possess strong tap root which is usually broken or arrested during transplanting, resulting in the development of profusely branched laterals as much as $1 \mathrm{~m}$ long. The entire root system remains restricted to the upper soil layer of $30 \mathrm{~cm}$ depth but more active feeding roots are found up to $10 \mathrm{~cm}$ depth from the base of the plant.

\subsection{Floral morphology}

The lanceolate leaves are either glabrous or pubescent. Flowers are either white or greenish white. The flowers of wild Capsicum species are pentamerous. They are bracteolate, actinomorphic, and pedicellate, bisexual, and hypogynous. However, large fruited cultivars may have 5 to 7 corolla lobes. Corilla is penapetalous and bell shaped. Calyx is carpanulate, sepals usally five gamosepalous, and is shorter than fruit. The stamens are normally 5 and alternate with the petals. Stigma is club shaped, subcarpitate and faintly bifid. Style is slender, terminal and linear. The ovary consists of 2 to 4 more locules.

\subsection{Pollination}

Chilli flowers open at 5 a.m. stigma becomes receptive from a day earlier to anthesis and remains so far 2 days after anthesis. Antherdehiscence takes place during morning hours $5.30 \mathrm{am}$ to $11.00 \mathrm{am}$. Depending upon temperature. Pollen grains become fertile a day before anthesis, with maximum fertility on the day of anthesis. Chilli is basically a self-pollinated crop but cross pollination to an extent of $16 \%$ has been reported. (Tikloo, 1991) ${ }^{[12]}$. To maintain purity of chilli variety, a minimum isolation of $400 \mathrm{~m}$ is considered safe. Normally, flowering in chilli commences 40 days after transplanting with a peak flower production at 60 to 80 days after transplanting. Peak flower production in chilli is influenced by soil moisture, soil fertility, and incidence of pest.

\subsection{Cultivation}

1.5.1 Climate: Chilli can be grown from equator to $45{ }^{\circ} \mathrm{C}$ in both hemispheres i.e. tropical and sub-tropical regions in areas with over $40{ }^{0} \mathrm{C}$ temperature. It is raised from sea level to 2000 meter above sea level. Optimum temperature for fruit set is $24{ }^{0} \mathrm{C}$. Night temperature below $10{ }^{\circ} \mathrm{C}$. The rainfall temperature requirement for chilli is $850-120 \mathrm{~mm}$ per annum and 20-25 degree centigrade respectively.

1.5.2 Selection of field: Chilli is a simpler crop to cultivate. The field should be selected chilli is soil well ploughed properly at the time of plating the crop. Low lying, water logged fields should be avoided. The soil should be light loamy with rich organic matters necessary for the satisfactory growth of the plant. Optimum soil $\mathrm{pH}$ for chilli is 5.8 to 6.5 . It also needs adequate soil moisture for growth. In India chilli are produced throughout the year and mostly cultivated as a rain fed crop.
1.5.3 Land Preparation: The land should be prepared by 4 to 5 ploughing and plant kings. All weeds and stubbles should be carefully removed from the soil otherwise these may lead to termite infestation and serious damage to chilli crop.

1.5.4 Seed selected and seed treatment: The seed must be true to type and should have high germination, vigour and good health. It should be bold and have uniform color and seed which is black, shrivelled, light in weight and has black spot in the centre, well not germinate and should not be used. The seeds should be treated with Thiram or Captan at the rate of 3 to $4 \mathrm{~g}$ per $\mathrm{kg}$ of seed before sowing, to check surface borne pathogens causing damping off during germination.

1.5.6 Nursery raising: Before sowing the seeds in nursery beds, it should be drenched with 1.0 to $1 \%$ formalin by applying 4 to 5 litres of solution per $\mathrm{m}^{2}$. Seeds are sown 1 to 2 $\mathrm{cm}$ deep in row, $5 \mathrm{~cm}$ spaced apart. Regular and appropriate watering is needed when the seeds are in sprouting stage. The irrigation should be with held 4 to 5 days before transplanting to harden the seedling

1.5.7 Transplanting: Transplanting is done in the afternoon time. The optimum spacing is $60 \mathrm{x} 45 \mathrm{~cm}$ for open field conditions. Immediate irrigation after transplanting facilitates better plant establishment. There after light and frequent irrigation should be given upto the establishment of plant.

\subsection{Seasonality}

Chilli grown as a seasonal and annul cash crop. Sowing of seeds starts in the first week July that is after the commencement of south west monsoon. The total growth period of this crop is around 4-6 months. Harvesting is done mainly in December after proper drying in sun the market starts from April.

\subsection{Fruit developing stage}

Chilli fruit is "berry" botanically. The berry develops from bicarpellary superior ovary and has an axile placentation. The major fruit components are seed, pericarp, placenta, and pedicle. The pericarp is leathery or succulent which turns from green or purple. The pedicle is short and thin. The placenta carries numerous seeds. All these components vary greatly depending on the variety and climatic conditions. The fruit may be elongate, oblate, round, conical, bell shaped. After anthesis, fruit gradually increases in size and shape. Seeds start developing 14 to 21 days after anthesis. It takes about 30-35 days from fruit set to complete development of fruit for harvesting at green stage. Fruit starts ripening 45-50 days after fruit set.

\subsection{Seed Development \& Storage}

Chilli seeds are born on the placental tissues. Seeds are compressed orbicular and minutely pitted.Seeds start developing 14 to 21 days after anthesis. Viability of seeds commences 35 days after anthesis and increases full maturity upto 50 days after an thesis. Seed are generally yellow colored and smooty at maturity. Thousand seed weight varies from 3.4 to $3.6 \mathrm{~g}$. Seeds are stored in cool dry facility, preferably at $4{ }^{\circ} \mathrm{C}$ or low temperature high in $20{ }^{\circ} \mathrm{C}$ maintains viability for more than 10 years (Murthy and Murthy, 1961) [6]. 


\subsection{Importance}

Pungency: Pungency in chilli is due to the alkaloid "Capsaicin" contained in the pericarp and placenta of fruits, it produces mild intense spice when eat in. Capsaicin is a potent inhibitor of substance $\mathrm{P}$, a neuropeptide associated with inflammatory processes. Thehotter the chilli pepper, the more capsaicin it contains. The hottest varieties include Naga Jalokia pepper.

Capsaicinoids: Chilli pepper gets its intensity from "capsaicin" and several other related phytochemicals collectively called as Capsaicinoids" capsaicin oleoresin is the main ingredient of the pepper spary while consuming chilli Capsaicinoids bind with the pain receptors in mouth and throat that are normally responsible for sensing heat, once the pain receptors are activated by the Capsaicinoids, these receptors send a message to the brain that the person has consumed something hot. The brain responds to the burning sensation by raising the heart rate, increasing perspiration and release of endorphins.

\subsection{Nutritional value of chilli}

Chilli comprises of the following nutrients Proteins, Carotenoids, Fat, Vitamin A, Vitamin C, Provitamines E, P, B1, B2, B3, Steroidal alkaloidal glycosides and cholesterol and sodium. Chilli's are low in saturated fat, cholesterol and sodium. It is high in Vitamin A, C, K, B6, Potassium, Copper, Manganese, dietary fiber, Thiamin, Riboflavin, Niacin, Folate, Iron, Magnesium, and Phosphorus. The nutritional values and health benefits of chilli are ideal for Maintaining optimum health and weight loss. While drying, chilli loses most of its vitamin $\mathrm{C}$, it increases the vitamin A content by 100 times. Vitamin $\mathrm{A}$ is a powerful anti-oxidant and antiinflammatory agent.

\subsection{Medicinal use}

Chilli extract have anticancer and anti-mutagenic effects. Carotenoids present in chilli extract were found to have anti mutagenic and anti-tumour promoting activity. Topical capsaicin has safe analgestic effect against many painful conditions. Capsaicin is responsible for cancer cell death in rats. Chilli helps in the control of LDC or bad cholesterol, which is the cause for cardiovascular disease. If chilli pepper is consumed in the meal the amount of insulin required to lower blood sugar is reduced.

\subsection{Health risks and precautions}

Chronic ingestion of hot pepper products may induce gastro esophageal reflux. Chilli may increase the number of daily bowel movement and lower pain threshold for people with irritable bowel syndrome. Chilli should not be swallowed as whole this may cause bowel obstruction and perforation.

\subsection{Breeding}

Hot pepper breeding the choice of breeding method depends on the breeding objective and the plant material being used as parents. The aim of Hot pepper breeding is to give a better plant with superior genetic potential for yield, protection against production hazards and improved quality. The Traditional breeding are: Mass selection, Pedigree method, Single Seed Descent -SSD method, Backcross method, Recurrent Selection. Molecular breeding techniques are: Molecular markers, Transformation.

\subsection{Traditional Breeding}

Mass selection: Seed of the best plant were saved for the next growing season; oldest method. This method should be used for population with genetic variability and selected in environment where the traits express themselves and for those of high heritability (Nsbyera et al., 2013) ${ }^{[7]}$.

Pedigree method: Keeping record of mating and their progeny. This includes making single plant selections and self-pollination (Oliveira et al., 2015) ${ }^{[8]}$.

Single Seed Descent method- SSD: This method involves the advance of generation without selection; it is also utilized in the development of recombinant inbred lines. Advancement of generation can be performed in greenhouse (Ulhoa et al., 2014) utilized this method to obtain lines restant to bacterial spot.

Backcross: Used particularly for traits controlled by one or few genes, which involves selection of individual plants and successive crosses to a recurrent parent (Prakash et al., 2014) [9].

Recurrent selection involves selection individuals from a population followed by intercrossing to form a new population (Singh et al., 2014) ${ }^{[10]}$.

\subsection{Molecular breeding}

Modern plant breeding uses techniques of molecular biology to select, or in the case of genetic modification, to insert, desirable traits into plants.

Marker Assisted selection: Different genes can influence a desirable traits in plant breeding. The use of tool such as molecular markers or DNA fingerprinting can map thousands of genes. Isozyme and molecular markers have been applied chilli. A saturated Isozyme and Restriction Fragment Length Polymorphism (RFLP) map of chilli has been reported. The map contains 192 chilli genomic DNA clones with 19 linkage groups with total coverage of $720 \mathrm{~cm}$. This area of research is rapidly adding to our knowledge of chilli's and will undoubtedly be important in the future.

\subsection{Tissue culture}

In vitro clonal propagation is a key tool of biotechnology that exploits totipotent nature of plant cells, a concept proposed by Haberlandt (1902) ${ }^{[3]}$. Tissue culture in combination with molecular techniques is used to incorporate specific traits through gene transfer. Highly efficient reproducible plant regeneration potential of chilli. To certain extent regeneration has been achieved through organogenesis other modes of such as protoplast to plant regeneration are also explored. Gunay and Rao (1978) ${ }^{[2]}$ marked the clear influence of cotyledon as explants in the hormone combination BA\&IAA for indirect somatic organogenesis in Capsicum annum and Capsicum frutescens species, for explant hypocotyls, epicotyles, stem leaf, root, shoot tip, embryo for direct and indirect organogenesis. seeds were used as explant for organogenesis in the hormone combination BA\&NAA by Ebida and $\mathrm{Hu}$ in $1993^{[1]}$. Direct and indirect somatic embryogenesis of mature and immature zygotic embryo was tested by Harini and Lakshmi sita (1993) ${ }^{[4]}$. For direct as well as indirect somatic embryogenesis MSmedia supplemented with Auxin and Thidiozuran (TDZ) recorded green and Shiny and maximum regeneration this combination was proposed by venkataiah et al., (2003) ${ }^{[14]}$. 


\subsection{Chilli Transformation}

Peculiar aspect of chillies is the inability to be regenerated. This limits the techniques of genetic transformation. For unexplained reasons chilli has been recalcitrant to being regenerated. Once this perplexing problem is solved, genetic transformation will be available to introduce novel genes in chilli. Traditional plant breeding techniques could not serve the increasing need for crop productivity but genetic transformation holds great promise to overcome all the barriers of traditional methods. Genetic manipulation is a DNA technology which could transfer gene to alleviate a specific purpose. In general Agrobacterium tumefaciens has been used as vector for genetic transformation. Agrobacterium is the only vector so far transformation of chilli, Liu et al., (1990) ${ }^{[5]}$.

\subsection{Insects and Pests affecting chilli plant}

1.18.1 Aphids (Aphis gossypi \& myzuspersicae)

Aphids are generally seen in plant which is in reproductive phase. It appears on tender shoots and leaves which sucks sap from leaves. It secretes a sweet substance which attracts ants and because of this it develops a black pod which will lose quality.

\subsubsection{Mite (Polyphagotarsonemus latus)}

Mites are major problems in chilli cultivation and it appears 40 days after sowing the seeds. Nymph and adult suck sap from leaves and the affected leaf curls to attain an inverted boat shape. Leaves turn dark grey in color, stops flowering and reduces yield. The fruits becomes hard and white strips appears on the fruits.

\subsubsection{Thrips (script thrips dorsalis)}

Thrips are the major pest affecting chilli crop throughout its life period. Adults and nymphs lace rate the leaf tissue and suck the sap. Tender shoots, buds and flowers are attacked and as a result they becomes twisted and deformed.

\subsubsection{Fruit borers (i) tobacco caterpillar (Spodoptera litura)}

In chilli the caterpillar damages the fruits by borings in to it. The affected pods drop off or develop white color on drying.

\subsubsection{Gram caterpillar (Helicoverpa armigera)}

Larvae damages by boring into fruits and feeds on inner contents of the pods. The entry hole is large and typically circular. The affected pod drops off.

\subsubsection{Ragi cut worm (Spodoptera exigua)}

It most damages leaves, flowers and tender pods. It feeds the fruit at the base of the calyx.

\subsubsection{Root grub (Holotrichia consanguinea)}

Grub always eats the nodules the fine rootlets and also gridle on the main root. It generally prefers young plants. The attacked plants can be easily identified and pulled out easily.

\subsubsection{White fly (Bemisia tabaci)}

Nymphs and adults suck on under surface of leaves and excrete honey dew causing contamination on lint. Leaves appear sick and it transmit leaf cural virus.

Helicoverpa armigera is the single important pest in the agriculture of southern Asia. It attacks a wide range of crops. It has become resistant to a range of crops. It has become resistant to a range of insecticides, resulting in increasing production coast and increased yield losses. It belongs to insect order Lepidoptera: noctuidae. The common names are, in English: old African bollworm, corn earworm, cotton bollworm.

Major factors affecting chilli crop loss are Insects and Pest, Virus and Herbicide tolerance. The major crops loss in chilli from insects and pest is $35 \%$, virus $24 \%$, herbicide is $2 \%$, and rest 39\% Identity. Chilli yield loss due to Helicoverpa armigera on plants in green house and field conditions. The yield reduction is around $11.1 \mathrm{q} / \mathrm{ha}$ respectively.

\section{Conclusion}

Plant tissue culture and genetic transformation are powerful tools that can complement traditional breeding methods and can be used in the improved production of capsicum. Molecular markers are used to characterize the genetic structure of individuals and populations. Plant breeders also use it as a tool in selection process, Via marker-assisted selection provides more detailed information of relationship and evolution about more than 20 alkaloids involved in process that gives pungency solely in Capsicum genus. Furthermore, the complete pepper genome sequencing allows advancement of new associations between genomic studies and important characteristics such as fruit size, fruit production, pungency, abiotic stress tolerance, nutritional content and disease resistance. Thus, the usage of new technologies will continue to advance becoming an essential tool, combined with traditional techniques of selection and crosses already established in Capsicum peppers genetic breeding. The most important aspect of chilli breeding is to incorporate pest, disease resistance varieties, while retaining high yield capacity.

\section{Reference}

1. Ebida AIA, Hu CY. In vitro morphogenic responses and plant regeneration from pepper (Capsium annum L.) L.CV. Early California wonder seedling explant. Plant Cell Rep. 1993; 13:107-10.

2. Gunay $\mathrm{AL}$, Rao Ps. In vitro plant regeneration from hypocotyl and cotyledon explants of red pepper (Capsicum). Plant Sci Lett, 1978; 11:365-72.

3. Haberlandt G, culturver such mit isolierten pflanzenzellen, Sitz -Ber-Math-Nat KI Kais AkadWiss Wien, 1902; 111:69-92

4. Lakshmi sita G, Harini I. Direct somatic embryogenesis and plant regenerarion from immature embryos of chilli (Capsicum annum. L). Plant sci. 1993; 89:107-12

5. Liu W, Parrott WA, Hilderbrand DF, Collins GB, Willims EG. Agrobacterium Induced Gall formation in bell pepper (Capsium annum L.) and formation of shootlike structure expressing introduced genes. Plant Cell Rep. 1990; 9:360-4

6. Murthy NSR, Murthy BS. Chilli seed viability in relation to period of storage. Andhra Agric. J. 1961; 8:61-64.

7. Nsabiyera V, Ochwo-ssemakula M, Sseruwagi P, Ojewo C. Combining ability for firld resistance to disease, fruit yield and yield factors among hot pepper (Capsicum annum L.) Genotypes in Uganda. International Journal of Plant Breeding, 2013; 7(1):12-21.

8. Oliveria KL, Bosland PW. Capsicums Innovative uses of an ancient crop. 2015, 479-487.

9. Prakesh MK, Peterson PA. Spices research and Development: An updated overview, Agro-In-dia. August, 2014, 16-18. 
10. Singh P, Cheema DS, Dhaliwal MS, Garg N. Heterosis and combining ability for earliness, plant growth, yield and fruit attributes in hot pepper (Capsicum annuum L.) involving genetic and cytoplasmic genetic male sterile lines. Scientia Horticulture, 2014; 168:175-188.

11. Sun C, Mao SL, Zhang ZH, Palloix A, Wang LH, Zhang BX. Resistance to anthranose (Colletotrichum acutatum) of Capsicum mature green and ripe fruit are controlled by a major dominant cluster of QTLs on chromosome P5. Scientia Horticulture. 2015; 181:81-88.

12. Tikloo SK. Crop management of solanaceous vegetables: Tomato, Brinjal and chillies. In Recent Advances in Tropical Vegetable Production, Kerala Agriculture University, Vellanika, India, 1991.

13. Wahyuni DL, Ma DH. Heterosis and correlation between F1 hybrids and their parents in pepper (Capsicum annuum). Servicio De Investigation. Agraria. 2013, 6165.

14. Venkataiah P, Christopher P, Subhash K. Thiadiozuran induced high frequency adventitious shoot formation and plant regeneration in (Capsicum annuum L.) J Plant Biotechnol. 2003; 5:245-50.

15. Wahyuni Y, Ballester AR, Sudarmonowati E, Bino RJ, Bovy AG. Secondary metabolites of Capsium Species and their importance in the human diet. Journal of Natural Products. 2013; 76(4):783-93. 